Наносистели, нанолатеріали, нанотехнології Nanosistemi, Nanomateriali, Nanotehnologii 2017 , т. 15, № 2, сc. 277-288
(C) 2017 ІМФ (Інститут металофізики ім. Г. В. Курдюмова НАН України) Надруковано в Україні. Фотокопіювання дозволено тільки відповідно до ліцензії

PACS numbers: 68.35.Ct, 68.37.Ps, 73.50.Bk, 73.50.Lw, 81.07.Bc, 84.60.Rb, 85.80.Fi

\title{
The Influence of Surface on Scattering of Carriers and Kinetic Effects in $n$-PBTE Films
}

\author{
M. A. Ruvinskii, O. B. Kostyuk, B. S. Dzundza, and V. I. Makovyshyn \\ Vasyl Stefanyk Precarpathian University, \\ Shevchenko Str., 57, \\ 76018 Ivano-Frankivsk, Ukraine
}

The influence of mechanisms of surface reflection of electrons on the experimental electrical transport and thermoelectric properties of $n$-PbTe films on various substrates are considered based on the Fuchs-Sondheimer and Mayer models. The thickness dependence of conductivity, Hall coefficient, and Seebeck coefficient of films based on PbTe are investigated. As shown, for the films on glassceramic substrates, mechanism of completely diffuse scattering of carriers $(p \approx 0)$ are implemented, and for the films obtained on fresh mica chips, mixed mechanism of specular-diffuse scattering of carriers is realized (scattering coefficient $p \approx 0.4$ ).

Вивчено вплив механізмів поверхневого відбивання електронів на експериментальне електроперенесення та термоелектричні властивості плівок $n$-PbTe на різних підкладинках на основі моделів ФуксаСондхаймера та Маєра. Досліджено залежність від товщини провідности, Голлового коефіцієнта і Зеєбекового коефіцієнта плівок на основі $\mathrm{PbTe}$. Показано, що для плівок на ситалових підкладинках реалізується механізм повністю дифузного розсіяння носіїв заряду $(p \approx 0)$, а для плівок, одержаних на свіжоприготовлених лоснякових кристаликах, мішаний дзеркально-дифузний механізм розсіяння носіїв (коефіцієнт розсіяння $p \approx 0,4$ ).

Изучено влияние механизмов поверхностного отражения электронов на экспериментальный электроперенос и термоэлектрические свойства плёнок $n$-PbTe на различных подложках на основе моделей ФуксаСондхаймера и Майера. Исследована зависимость от толщины проводимости, коэффициента Холла и коэффициента Зеебека плёнок на основе $\mathrm{PbTe}$. Показано, что для плёнок на ситалловых подложках реализуется механизм полностью диффузного рассеяния носителей заряда $(p \approx 0)$, а для плёнок, полученных на свежеприготовленных слюдяных кристалликах, - смешанный зеркально-диффузный механизм рассеяния носителей (коэффициент рассеяния $p \approx 0,4$ ). 
Key words: size effect, thin film, lead telluride, thermoelectric properties.

Ключові слова: розмірний ефект, тонка плівка, телурид свинцю, термоелектричні властивості.

Ключевые слова: размерный эффект, тонкая плёнка, теллурид свинца, термоэлектрические свойства.

(Received 27 December, 2016)

\section{INTRODUCTION}

Lead telluride is well-known thermoelectric material for semiconductor technology. Interest in research of it is not reduced over the years due to the unique physical and chemical properties. As it is a narrow semiconductor $A^{4} B^{6}$, so it is suitable for use in infrared lasers, optical detectors, and a thermoelectric material in average temperatures $(500-750 \mathrm{~K})$ [1-3]. In thin films, due to the transition from $2 D$ to $3 D$ material, new dimensional effects occur in profiles of thermoelectric parameters.

Today the problem of calculation of the conductivity of thin films is particularly relevant due to the rapid development of micro- and nanoelectronics. Necessity of modern society in new energy sources is accompanied by the rapid development of thermoelectric material.

Many studies considered that the scattering coefficient $p$ for semiconductor films is zero. However, this is not always true [4]. In this paper, the influence of mechanism of surface reflection of electrons on the thermoelectric properties of $n$-PbTe films on various substrates is considered, and the thickness dependence of the Seebeck coefficient of films based on PbTe is investigated.

\section{EXPERIMENTAL DETAILS}

Films for research are obtained by vapour deposition of synthesized material $n$-PbTe in a vacuum on the substrate of fresh chips (1000) of mica-muscovite and sitall. The temperature of the evaporator was $T_{e}=870 \mathrm{~K}$, and the temperature substrates $T_{s}=470 \mathrm{~K}$. The thicknesses of films are set by the deposition time of $0.5-13 \mathrm{~min}$ and are measured by microinterferometer MII-4.

Measurement of electrical parameters of films was carried out on air at room temperature and at constant magnetic field on the automated device. It provides a process for measuring electrical parameters and initial registration and processing of data. Measured sample had four Hall contacts and two current contacts. As the ohmic contacts, a silver film was used. The current through the 
sample was $\cong 1 \mathrm{~mA}$. The magnetic field was directed perpendicularly to film surface. The induction of magnetic field was 1.2 Tesla.

For measurements of the Seebeck coefficient $S$, an integral method was used. One end of film had a constant temperature, and the temperature of other end was changed. The ends of film were attached to the massive copper plates to provide a constant temperature. For the measurement of temperature, platinum thermoresistors were used. The sign of $R_{H}$ and $S$ define type of carriers.

Dependences of conductivity $\sigma$, Hall coefficient $R_{H}$, mobility $\mu$, Seebeck coefficient $S$ on the thickness of $n$-PbTe films is shown in Figs. 1-8. Calculations of the $\sigma(d), R_{H}(d), \mu(d)$, and $S(d)$ dependences were performed with the use of mathematical package Maple 18.

\section{ELEMENTS OF THEORY}

The thin film has many sources of scattering of electrons. In our paper, the size effects associated with scattering on the outer surfaces of film are considered. Fuchs and Sondheimer examined the dependence of the current density $j(z)$ on the film thickness $d$ in detail in works $[5,6]$. Conductivity of film $\sigma$ is determined from the kinetic Boltzmann equation, taking into account boundary conditions according to [5]:

$$
\frac{\sigma}{\sigma_{b}}=1-\frac{3}{8 k}+\frac{3}{2 k} \int_{1}^{\infty}\left(\frac{1}{t^{3}}-\frac{1}{t^{5}}\right) \exp (-k t) d t,
$$

where $\sigma_{b}$-electrical conductivity of bulk samples, dimensionless thickness equals to the film thickness divided to the length of the average free path of electrons $l$ :

$$
k=d / l \text {. }
$$

For the limiting case of $k>>1$ (thick film), we obtain [6]:

$$
\sigma=\sigma_{b}\left(1+\frac{3}{8 k}(1-p)\right)^{-1}(k>>1) .
$$

For quite thin films $(k<<1)$,

$$
\sigma=\sigma_{b} \frac{3}{4} \frac{1+p}{1-p} k \ln \frac{1}{k}(k<<1) .
$$

Here, $p$-the scattering coefficient (i.e., probability of specular reflection); $0 \leq p \leq 1$. When $p=0$, it is a diffuse reflectance; $p=1$ corresponds to a pure specular reflection; and if $0<p<1$, there is a mixed specular-diffuse reflection. The case of a massive film is 
realized with $d \rightarrow \infty$.

The Fuchs-Sondheimer model is based on the assumption that the statistical properties of the upper and lower surfaces of film can be described by the same parameter $p$. However, by the example of gold films, Lucas [7] experimentally showed that the scattering processes on surfaces vary independently. In work [8], it was suggested that the conductivity of film is characterized by two parameters: scattering at the interface of film and free surface, $p$, and scattering at the interface of film and substrate, $q$. For the thick films, equation for $\sigma$ has the form:

$$
\sigma \approx \sigma_{b}\left[1+\frac{3}{8 k}\left(1-\frac{p+q}{2}\right)\right]^{-1}(k>>1) .
$$

Let us consider the manifestation of size effect in dependence of Hall coefficient $R_{H}$ on thickness in case of directional magnetic field perpendicular to the surface of film and the current direction. Within the Sondheimer model, Hall coefficient can be determined from the following equation [6]:

$$
R_{H}=R_{H b} \frac{4}{3} \frac{1-p}{1+p} \frac{1}{k}\left(\ln k^{-1}\right)^{-2}(k<<1) .
$$

It should be mentioned that Sondheimer considered only the region of small $k$, because the Hall coefficient is mainly affected by the external surface of scattering at low thicknesses.

In Ref. [9], the analytical expression for the Hall coefficient is given and relatively easy leads to numerical evaluation of $R_{H}$ :

$$
R_{H}=R_{H b} B\left(A^{2}+\xi^{2} B^{2}\right)^{-1},
$$

where $\xi=l / D$-reduced mean free path ( $D$-Larmor radius),

$$
\begin{aligned}
& A=\frac{3}{2} \times \\
& \times\left\{-\frac{1}{2} \mu+\mu^{2}+\frac{\mu\left(1-\mu^{2}+\xi^{2} \mu^{2}\right)}{2} \ln \frac{\left(1+\mu^{-1}\right)^{2}+\xi^{2}}{1+\xi^{2}}-2 \xi \mu^{3} \tan ^{-1}\left(\frac{\xi}{\mu} \frac{1}{\xi^{2}+1+\mu^{-1}}\right)\right\}, \\
& B=\frac{3}{2}\left\{-\mu^{2}+\mu^{3} \ln \frac{\left(1+\mu^{-1}\right)^{2}+\xi^{2}}{1+\xi^{2}}+\frac{\mu\left(1-\mu^{2}+\xi^{2} \mu^{2}\right)}{\xi} \tan ^{-1}\left(\frac{\xi}{\mu} \frac{1}{\xi^{2}+1+\mu^{-1}}\right)\right\}, \\
& \mu=k\left[\ln \left(p^{-1}\right)\right]^{-1} .
\end{aligned}
$$


Experimentally obtained the thickness-dependent mobility $(\mu)$ can be explained by the mechanisms of carrier scattering on the surface of the condensate. The mobility of carriers in case of diffuse scattering on the surface is defined as follows [9]:

$$
\mu=\mu_{b}(1+k)^{-1} ;
$$

here, $\mu_{b}$-the mobility of carriers in the bulk material.

According to works of E. Justi [10] and H. Mayer [11], thermose.m.f. $S$ of films with a thickness $d>l$ is given as follows:

$$
S=S_{b}\left[1-\frac{3}{8} \frac{l}{d} \frac{U}{1+U}(1-p)\right] .
$$

For thin films with a thickness $d<<l$,

$$
S=S_{b}\left[1+\frac{U}{1+U} \frac{\ln \left(\frac{l}{d}\right)-1.42}{\ln \left(\frac{l}{d}\right)-0.42}\right], p \cong 0,
$$

where $S_{b}$-Seebeck coefficient for bulk samples, and parameter $U=(\partial \ln l(E) / \partial \ln E)_{E=\xi}$ characterizes the energy-dependent $l, E-$ energy of electron, $\xi-$ Fermi energy. In the quadratic dispersion law, $U=2$ is predicted by the Bloch's free-electron hypothesis.

\section{THE RESULTS AND DISCUSSION}

Theoretical dependence and experimental data for conductivity $\sigma$, Hall coefficient $R_{H}$, mobility $\mu$, Seebeck coefficient $S_{x}$ on the thickness of films based on $n$-PbTe are shown in Figs. $1-8$. For the massive-sample parameters, experimental data for sufficiently thick films, which are well consistent with data for bulk samples [12], were used:

for the film on mica substrates: $\sigma_{b}=150 \mathrm{Ohm}^{-1} \cdot \mathrm{cm}^{-1}, R_{H b}=-0.75$ $\mathrm{cm}^{3} / \mathrm{C}, \mu_{b}=158 \mathrm{~cm}^{2} / \mathrm{V} \cdot \mathrm{s}, S_{b}=-120 \mu \mathrm{V} / \mathrm{K}$;

for the film on sitall substrates: $\sigma_{b}=9 \mathrm{Ohm}^{-1} \cdot \mathrm{cm}^{-1}, R_{H b}=-3.5 \mathrm{~cm}^{3} / \mathrm{C}$, $\mu_{b}=27 \mathrm{~cm}^{2} / \mathrm{V} \cdot \mathrm{s}, S_{b}=-93 \mu \mathrm{V} / \mathrm{K}$.

Figures 1 and 2 show the dependence of conductivity $\sigma$ on the film thickness of $n$-PbTe on mica substrates and experimental data. As seen, with increasing film thickness $d$, conductivity increases greatly with reached saturation at $d \approx 300 \mathrm{~nm}$ for samples on mica substrates and at $d \approx 600 \mathrm{~nm}$ for samples on sitall ones. In this case, dimensional effects have a significant impact, which is vanishing with increasing thickness. The theoretical curve was calculated us- 


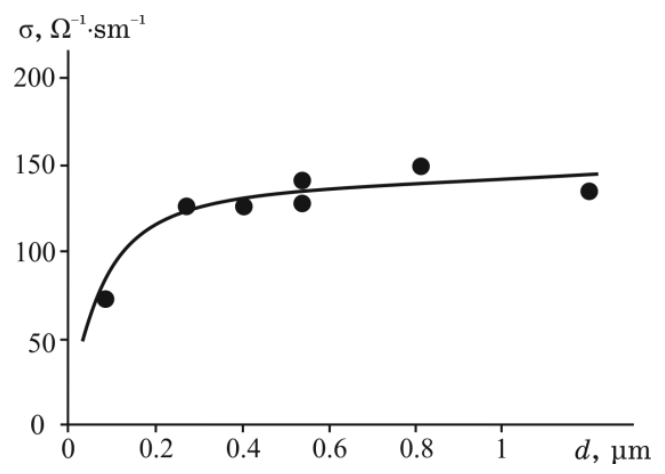

Fig. 1. Thickness dependence of conductivity $\sigma$ of the $n$-PbTe films on fresh chips of (1000) mica-muscovite. Points-experiment, solid linecalculation models according to Fuchs-Sondheimer theory.

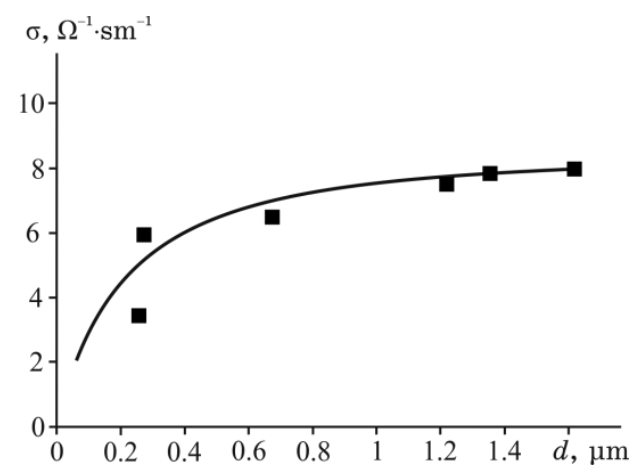

Fig. 2. Thickness dependence of conductivity $\sigma$ of the $n$-PbTe films on sitall. Points-experiment, solid line-calculation models according to Fuchs-Sondheimer theory.

ing the formula (3), and parameter $p$, and $l$ was found. Best matches of theoretical curve and experimental data were obtained by the least squares method with special features in the Maple 18. The calculated values for the reflectivity coefficient were as follow: $p=0.4$, $q=0.37$ for the films on mica, and $p=0.08, q=0.03$ for the films on sitall. Note that the values of coefficients of specular scattering are comparable for both surfaces of film (Table 1).

Regarding the impact of the type of substrate, for the films obtained on fresh chips of mica, specular-diffuse scattering mechanism of carriers is realized, and for the films on sitall, scattering mechanism of carriers closes to diffuse one completely $(p \cong 0)$. This is due to higher structural perfection of films on mica unlike films on sitall. 
The dependence of Hall coefficient on the thickness was calculated according to Eq. (6) (Fig. 3; Fig. 4, curve 1). For films on mica (Fig. 3), calculation for Eq. (6) satisfactorily describe experimental data, and for the films on sitall, Eq. (6) only describes the range of thin films, as noted by Sondheimer in Ref. [5]. Therefore, to describe the dependence of the Hall coefficient on the thickness, numerical score with (7) proposed by Tellier et al. [9] was applied (Fig.

TABLE 1. The calculated values of parameter for the specular scattering of carriers.

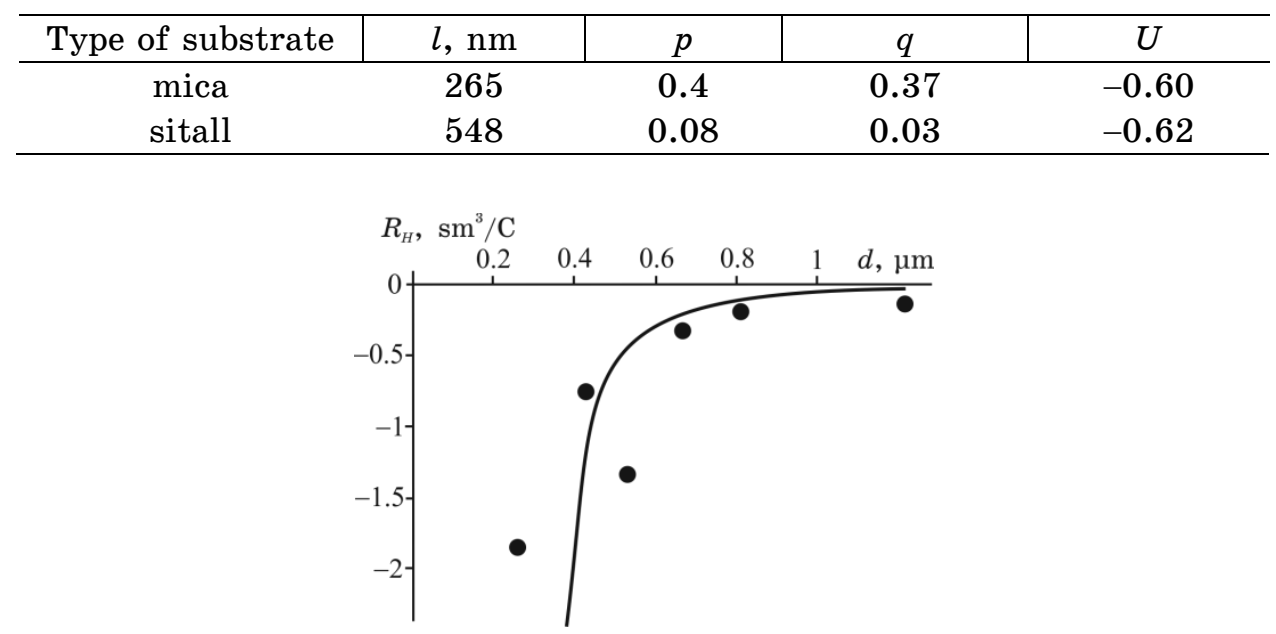

Fig. 3. Thickness dependence of Hall coefficient $R_{H}$ of the $n$-PbTe films on fresh chips of (1000) mica. Points-experiment, solid line-calculation models according to Fuchs-Sondheimer theory.

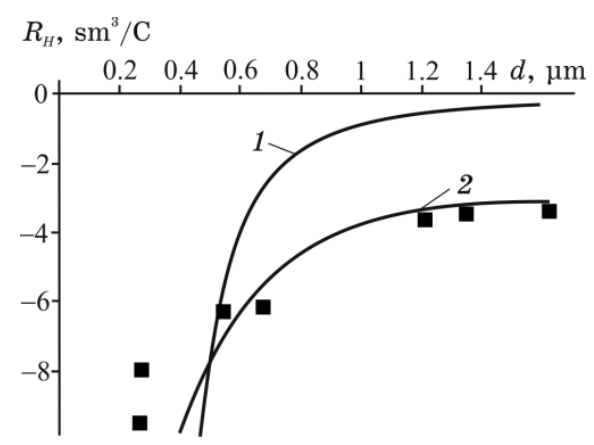

Fig. 4. Thickness dependence of Hall coefficient $R_{H}$ of the $n$-PbTe films on sitall. Points-experiment, solid lines-calculation models according to Fuchs-Sondheimer theory. 


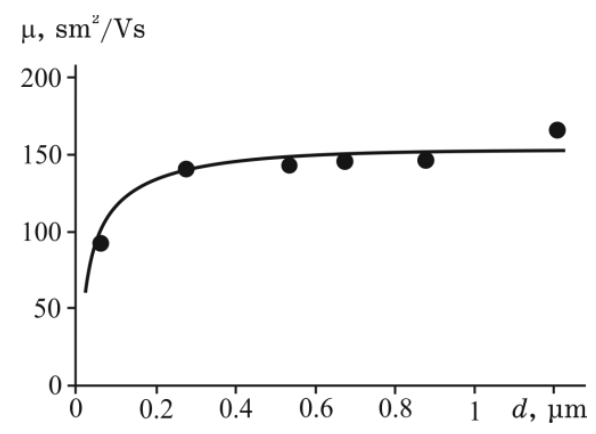

Fig. 5. Thickness dependence of Hall mobility $\mu$ of the $n$-PbTe films on fresh chips of (1000) mica. Points-experiment, solid line-calculation models according to Fuchs-Sondheimer theory.

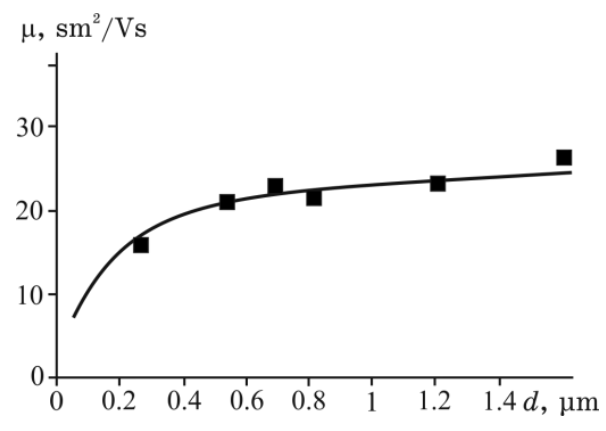

Fig. 6. Thickness dependence of Hall mobility $\mu$ of the $n$-PbTe films on sitall. Points-experiment, solid line-calculation models according to Fuchs-Sondheimer theory.

4, curve 2).

The Larmor radius was calculated by the method of the least squares $D=4.25 \cdot 10^{-7} \mathrm{~m}$. This result coincides well with the calculation by the first approximation with the formula $D=m v /(e B)$, where $m$-mass of carrier, $e$-module of charge, $B$-magnetic field, $v$-velocity of carrier. For these films, $D=4.59 \cdot 10^{-7} \mathrm{~m}$.

Figures 6 and 7 present the dependence of Seebeck coefficient $S$ on the thickness of the $n$-PbTe film under the proposed model for substrates from mica-muscovite and sitall. For the films on mica, solid curve in Fig. 7 is calculated according to Eq. (9). For these samples, the theory for the thick films well coincides with experiment. The value of $U=-0.6$ was obtained by the least-squares method. It indicates a deviation from a quadratic dispersion law $(U=2$ for quadratic dispersion law).

Various researches give different values of $U$. Huebner [13] ob- 


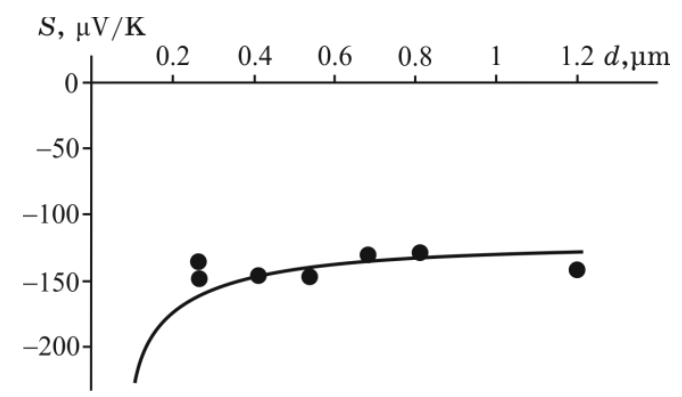

Fig. 7. Thickness dependence of Seebeck coefficient $S$ of the $n$-PbTe films on fresh chips of (1000) mica. Points-experiment, solid line-calculation models according to Mayer theory.

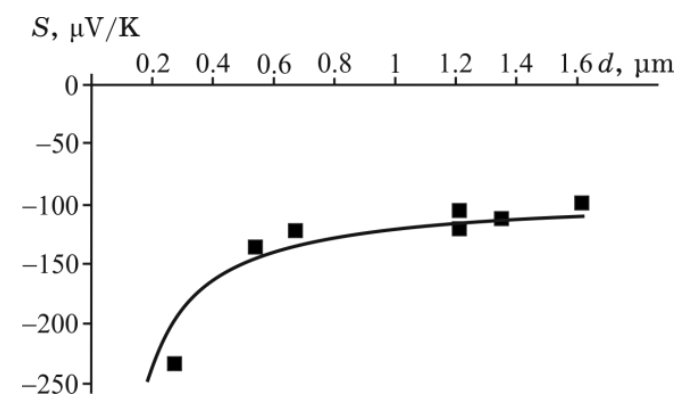

Fig. 8. Thickness dependence of Seebeck coefficient $S$ of the $n$-PbTe films on sitall. Points-experiment, solid line-calculation models according to Mayer theory.

tained $U=-0.53 \pm 0.19$ for the thin gold film at the temperature between $77 \mathrm{~K}$ and $296 \mathrm{~K}$. Chopra et al. [14] obtained $U=-18.7$ for the thin copper films at $T=483 \mathrm{~K}$. Thornburg and Wayman [15] obtained $U \approx-2.2$ for the thin $\mathrm{Au}-\mathrm{Ni}$ films.

For the films on sitall, similar behaviour was observed. The laws for the thick films described the experimental data. The value $U=-0.62$ was obtained by the least-squares method for the mica substrates.

It is also worth noting that the examined samples have relatively high Seebeck coefficient $S \cong 200 \mu \mathrm{V} / \mathrm{K}$. However, higher values of conductivity $\sigma$ for the films on mica give greater thermoelectric figure of merit for the films on mica, $S^{2} \sigma \cong 4 \mu \mathrm{W} / \mathrm{K}^{2} \cdot \mathrm{cm}$, compared with films on sitall, $S^{2} \sigma \cong 0.4 \mu \mathrm{W} / \mathrm{K}^{2} \cdot \mathrm{cm}$.

An important parameter that affects to the value of the scattering coefficient is surface roughness, $z$. Ziman [16] proposed a model, in which, by analogy with optics, there is possibility of obtaining mathematically exact expression for the scattering coefficient $p$. 
Then, according to [16], $p$ is defined as

$$
p=\exp \left(-16 \pi^{3} z^{2} / l^{2}\right),
$$

where $z$-standard deviation for the height from the reference plane (surface roughness), $l$-mean free path.

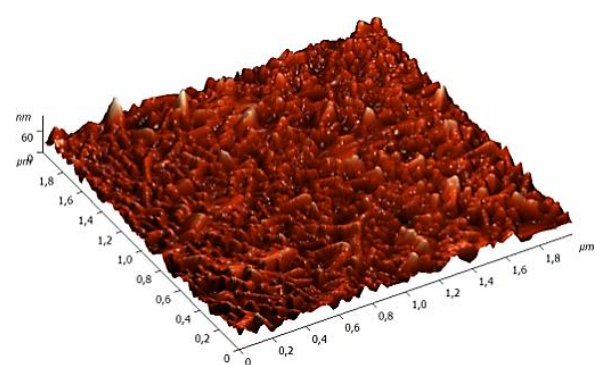

$1 a$

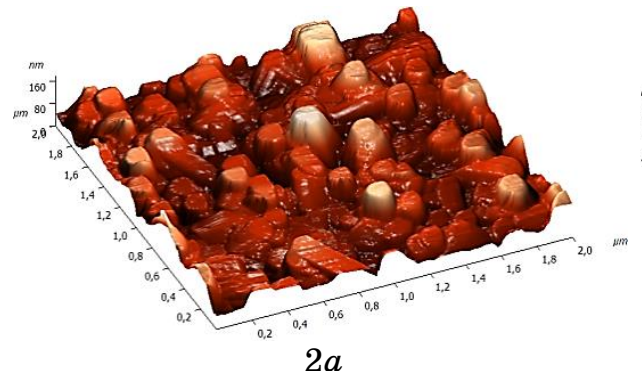

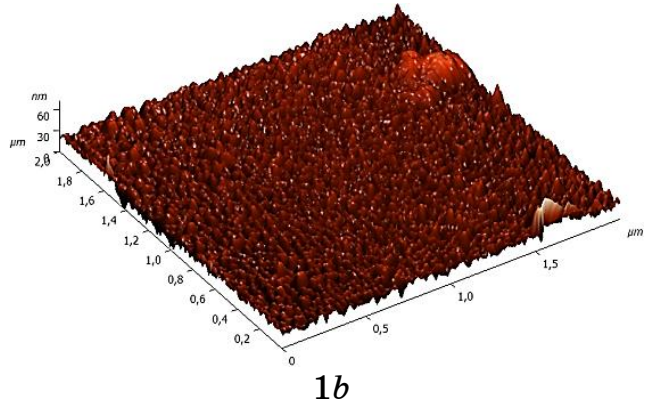

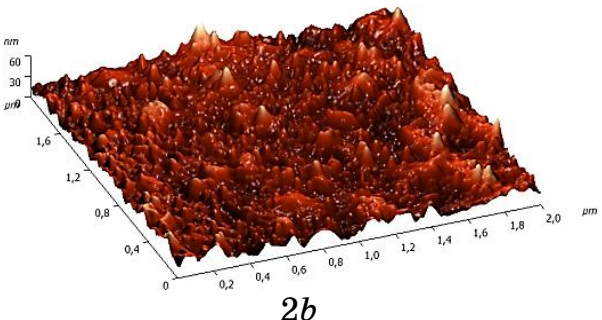

Fig. 9. $3 D$ AFM image of the surface of thin $\mathrm{PbTe}$ films deposited on chips (0001) mica-muscovite (1) and ceramics (2) with thickness, $d, \mathrm{~nm}: 270$ (1b and $2 b), 810(1 a), 1350(2 a)$.

TABLE 2. Dependence of the scattering coefficient on the surface roughness.

\begin{tabular}{|c|c|c|c|c|c|c|c|}
\hline \multicolumn{4}{|c|}{ mica } & \multicolumn{4}{|c|}{ sitall } \\
\hline 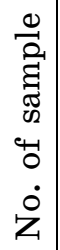 & 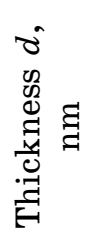 & 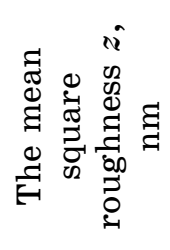 & 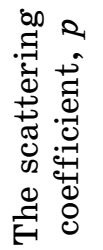 & 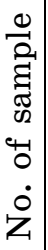 & 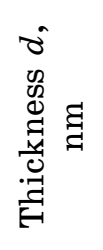 & 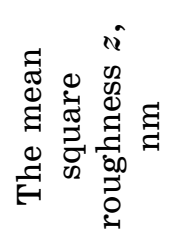 & 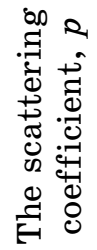 \\
\hline $1 a$ & 810 & 10.62 & 0.45 & $2 a$ & 1350 & 35.67 & 0.12 \\
\hline $1 a_{2}$ & 540 & 6.73 & 0.73 & $2 b$ & 270 & 6.77 & 0.93 \\
\hline $1 b$ & 270 & 5.02 & 0.84 & & & & \\
\hline
\end{tabular}


Figure 9 presents AFM images of a surface of studied films based on $\mathrm{PbTe}$. We see that the surface of film consists of nanosize crystallites of pyramidal shape. It is established that the average size of the nanocrystals increased with the thickness of condensate and the surface roughness increased (Fig. 9). The substrate of film does not significantly affect to the form of nanocrystals. However, the size of crystallites for the films on sitall is larger than for the films on mica. Accordingly, the surface roughness for the films on a mica substrate is less than for the films on a sitall substrate (Fig. 9, Table 2).

The calculated values of the scattering coefficient depending on the roughness are shown in Table 2 . As seen, for the coefficient $p$, a clear dependence on the thickness of condensate for studied samples is traced: it increases with the decreasing film thickness. For the thin films, $p$ is close to one that is indicating the mirror mechanism of carrier scattering from the surface of film. In other words, minor irregularities of surface, which are compared to the mean free path $l$, are not strongly impact on the characteristics of carriers' flow. It should be noted that the formula (11) is a fairly approximation, and description of the surface with only one parameter $z^{2}$ is rather simplistic. For the thick films, the scattering coefficient $p$ is smaller and quite close to the values calculated within the FuchsSondheimer model (Tables 1, 2).

\section{CONCLUSIONS}

1. The analysis on theoretical calculation of electrical parameters of films based on the Fuchs-Sondheimer and Mayer models.

2 . The electrical parameters of $n$-PbTe films on substrates of mica and sitall are experimentally studied. The influence of mechanism of surface reflection of electrons on the thickness dependence of conductivity, Hall coefficient, and thermo-e.m.f. is determined.

3 . The probability of specular scattering of charge carriers on both the free surface of film and the film-substrate boundary is determined. As shown, for the films on sitall substrates, completely diffuse scattering of carriers $(p \cong 0)$ is implemented, and for the films obtained on fresh chips of mica, the scattering coefficient $p \cong 0.4$.

\section{REFERENCES}

1. D. M. Freik, S. I. Mudryi, I. V. Gorichok, R. O. Dzumedzey,

O. S. Krynytskyi, and T. S. Lyuba, Ukr. J. Phys., 59, No. 7: 706 (2014).

2. L. P. Bulat, D. A. Pshenay-Severyn, and V. B. Osvenskyy, Fiz. Tverd. Tela, 58, No. 8: 1483 (2016) (in Russian).

3. U. P. Khairnar, S. S. Behere, and P. H. Pawar, Journal of Chemical, 
Biological and Physical Sciences, 2, No. 3: 1529 (2012).

4. M. A. Ruvinskii, O. B. Kostyuk, B. S. Dzundza, Journal of Nano- and Electronic Physics, 8, No. 2: 02051-1 (2016).

5. $\quad$ K. Fuchs, Proc. Cambridge Phil. Soc., 34: 100 (1938).

6. E. H. Sondheimer, Phys. Rev., 80: 401 (1950).

7. $\quad$ M. S. P. Lucas, Appl. Phys. Lett., 4: 73 (1964).

8. $\quad$ M. S. P. Lucas, J. Appl. Phys., 36: 1632 (1965).

9. C. R. Tellier, M. Rabel, and A. J. Tosser, J. Phys. F: Metal Phys., 8: 2357 (1978).

10. E. Justi, K. Kohler, and G. Lautz, Z. Naturforsch., 6A: 456 (1951).

11. H. Mayer, Physik dünne Schichten [Physics of Thin Layers] (Stuttgart: Wissenschaftliche-Verlagsgesellschaft MBH: 1955) (in German).

12. Ihor Horichok, Rasit Ahiska, Dmytro Freik, Lyubomyr Nykyruy, Stepan Mudry, Ostap Matkivskiy, and Taras Semko, Journal of Electronic Materials, 2015. (DOI 10.1007/s11664-015-4122-9).

13. R. P. Huebner, Phys. Rev., 136A: 1740 (1964).

14. K. L. Chopra, S. K. Bahl, and M. R. Randlett, J. Appl. Phys., 39: 1525 (1968).

15. D. D. Thornburg and C. M. Wayman, J. Appl. Phys., 40: 3007 (1969).

16. J. M. Ziman, Electrons and Phonons (London: Oxford University Press: 1962). 